\title{
Intake of supplementary food during pregnancy and lactation and its association with child nutrition in Timor Leste
}

\author{
Sanni Yaya ${ }^{1}$, Ruoxi Wang ${ }^{2}$, Shangfeng Tang ${ }^{2}$, Bishwajit Ghose ${ }^{\text {Corresp. } 1,3}$ \\ ${ }^{1}$ School of International Development and Global Studies, University of Ottawa, Ottawa, Ontario, Canada \\ 2 School of Medicine and Health Management, Tongji Medical College, Wuhan, Hubei, China \\ 3 Institution of Nutrition and Food Sciences, University of Dhaka, Dhaka, Bangladesh \\ Corresponding Author: Bishwajit Ghose \\ Email address: brammaputram@gmail.com
}

Abstract There is little evidence on maternal consumption of supplementary food on nutritional status of children. The objectives of this study were to measure the prevalence and determinants of supplementary food intake during pregnancy and lactation, and their association with nutritional status of under-five children in Timor Leste. Methods Crosssectional data from Timor Leste Demographic and Health survey on 5993 mother (15-49 years) child dyads ( $<5$ years) were included in the analysis. Self-reported intake of supplementary food intake was the explanatory variable. Child's nutritional status was assessed by stunting, wasting and underweight and categorised according to WHO recommendations. Results The prevalence of taking supplementary food during pregnancy and lactation was respectively $29.1 \%(95 \% \mathrm{Cl}=27.2-31.0) 31.0 \%(95 \% \mathrm{Cl}=29.1$ $33.0)$, and that of taking iron supplement during pregnancy was close to three-fifth $(63.1 \%$, $95 \% \mathrm{Cl}=60.9-65.3)$. The odds of taking supplementary food during pregnancy and lactation were lower among those in the younger age groups and higher among urban residents. Compared with mothers who had supplementary food during pregnancy and lactation, those did not have had respectively $1.36(\mathrm{OR}=1.360,95 \% \mathrm{Cl}=1.191-2.072)$ and 1.15 times $(\mathrm{OR}=1.152,95 \% \mathrm{Cl}=1.019-1.754)$ higher odds of having stunted, and 1.30 $(\mathrm{OR}=1.307,95 \% \mathrm{Cl}=1.108-1.853)$ and $1.43(\mathrm{OR}=1.426,95 \% \mathrm{Cl}=1.140-1.863)$ times higher odds of having underweight children. Those who had none of the supplements had respectively $1.67(\mathrm{OR}=1.674,95 \% \mathrm{Cl}=1.118-2.087)$ and $1.63(\mathrm{OR}=1.631,95 \% \mathrm{Cl}=1.130$ 2.144) times higher odds of having stunted and underweight children. Conclusion A great majority of the mothers in Timor Leste are not taking supplementary food during pregnancy and lactation. We found a positive relationship between supplementary food intake during pregnancy and lactation with stunting and wasting among under-five children. 
1 Intake of supplementary food during pregnancy and lactation and its association with child

2 nutrition in Timor Leste

6 Sanni Yaya $^{1^{*}} \quad$ Ruoxi Wang ${ }^{2 *} \quad$ Shangfeng Tang ${ }^{2} \quad$ Ghose Bishwajit $^{1,3}$

71 School of International Development and Global Studies, University of Ottawa, Ottawa, 8 Canada

92 School of Medicine and Health Management, Tongji Medical College, Wuhan, China

103 Institute of Nutrition and Food Science, University of Dhaka, Dhaka, Bangladesh. 
40 Abstract

41 There is little evidence on maternal consumption of supplementary food on nutritional status of children.

42 The objectives of this study were to measure the prevalence and determinants of supplementary food

43 intake during pregnancy and lactation, and their association with nutritional status of under-five children in

44 Timor Leste.

45

Methods

Cross-sectional data from Timor Leste Demographic and Health survey on 5993 mother (15-49 years) child dyads ( $<5$ years) were included in the analysis. Self-reported intake of supplementary food intake was the explanatory variable. Child's nutritional status was assessed by stunting, wasting and underweight and categorised according to WHO recommendations.

\section{Results}

52 The prevalence of taking supplementary food during pregnancy and lactation was respectively $29.1 \%(95 \% \mathrm{Cl}=27.2-31.0) 31.0 \%(95 \% \mathrm{Cl}=29.1-33.0)$, and that of taking iron supplement during pregnancy was close to three-fifth $(63.1 \%, 95 \% \mathrm{Cl}=60.9-65.3)$. The odds of taking supplementary food during pregnancy and lactation were lower among those in the younger age groups and higher among urban residents. Compared with mothers who had supplementary food during pregnancy and lactation, those did not have had respectively $1.36(\mathrm{OR}=1.360,95 \% \mathrm{Cl}=1.191-2.072)$ and 1.15 times $(\mathrm{OR}=1.152,95 \% \mathrm{Cl}=$ 1.019-1.754) higher odds of having stunted, and $1.30(\mathrm{OR}=1.307,95 \% \mathrm{Cl}=1.108-1.853)$ and 1.43 $(\mathrm{OR}=1.426,95 \% \mathrm{Cl}=1.140-1.863)$ times higher odds of having underweight children. Those who had none of the supplements had respectively $1.67(\mathrm{OR}=1.674,95 \% \mathrm{Cl}=1.118-2.087)$ and $1.63(\mathrm{OR}=1.631$, $95 \% \mathrm{Cl}=1.130-2.144)$ times higher odds of having stunted and underweight children.

\section{Conclusion}

A great majority of the mothers in Timor Leste are not taking supplementary food during pregnancy and lactation. We found a positive relationship between supplementary food intake during pregnancy and lactation with stunting and wasting among under-five children.

Key words: Supplementary food, Stunting; Wasting; Underweight; Timor Leste. 


\section{Introduction}

Regular consumption of a varied and balanced diet from preconception through pregnancy and postpregnancy period is of paramount importance to ensure healthy birth outcomes as well as optimum nutritional status of the mother and her newborn (Abu-Saad \& Fraser, 2010; Marangoni et al., 2016). Maternal undernutrition/inadequate dietary intake is strongly correlated with poor growth of the fetus in utero and post-nataly with demonstrated enhanced susceptibility for developing chronic diseases e.g. high blood pressure, type-2 diabetes, and neurological disorders in the later stages of life (Belfort et al., 2008; Wen et al., 2011; Brenseke et al., 2013; Keenan et al., 2013; Szostak-Wegierek, 2014; Blumfield et al., 2015). Various metabolic adaptations that take place to meet the increased nutritional demand involve hormonal mechanisms that play crucial roles in regulating appetite and eating behavior (Hirschberg, 2012). Although pregnancy embodies many of the factors that are known to trigger hyperphagia/overeating (van der Wijden et al., 2014; Orloff et al., 2016), exceptions are also widespread as a lot of women experience frequent bouts of food aversions and anorexia nervosa (Bayley et al., 2002; Dinas et al., 2008; Bulik et al., 2009) and share higher risks of miscarriage, intrauterine growth restriction, still birth, low birthweight (Koubaa et al., 2005; Bulik et al., 2009). The situation is particularly complex for women who are already malnourished and enter pregnancy with certain nutritional deficiencies.

In low-income settings, maternal malnutrition during pregnancy and lactation is a common phenomenon and is most often associated with inadequate intakes of specific micronutrients, resulting in adverse birth and health consequences for the child e.g. preterm birth due to zinc deficiency, and low birth weight due to iron/folic acid deficiency, cretinism due to iodine deficiency (Abu-Saad \& Fraser, 2010; Gernand et al., 2016). To account for the rising nutritional demand during pregnancy and lactation, women attending antenatal care are encouraged to undergo nutritional assessment, given dietary counselling, and routinely prescribed to take supplementary food enriched in micronutrients to meet the recommended dietary allowances (RDAs) (Tsui, Dennehy \& Tsourounis, 2001; Khanal, Zhao \& Sauer, 2014; Abdullahi et al., 2014). Setting RDAs for various micronutrients for pregnant mothers is challenging as it is dependent on a host of physiological factors. However, RDAs determined by local experts in nutrition such as registered dietitians are specific in guiding intakes for women in accordance with their nutritional status, dietary behavior, cultural preferences to ensure optimum pre- and post-natal nutrition for mother and her child. Despite the existing research base on dietary guidelines and maternal nutrition promotion programs, achieving optimum nutritional status continues to be a challenging task especially in low-income settings due to lack of nutrition education, access to appropriate food and diverse sociodemographic structure of the population (Lowdon, 2008).

Apart from maintaining a balanced diet, encouraging the intake of supplementary food has also been a popular strategy for addressing the problem of micronutrient deficiency among pregnant women. 
114 However, assessing the beneficial effects of maternal supplementation programs on fetal and childhood 115 nutrition is complex owing to the interplay of a range of behavioral, environmental, psychosocial factors 116 that vary widely across cultures (Abu-Saad \& Fraser, 2010). Also, the impacts of such programs may not 117 be universal as studies have produced mixed outcomes across and within countries, implying the 118 influence of population contextual factors in the responsiveness of different supplementation programs. From this perspective, assessing the relationship between supplementary food intake at various stages of pregnancy and lactation on child's nutritional status carry special importance as it provides the basis for making effective nutrition policies targeting the contextual situation and health needs of a population. To this end, we conducted this study based on a national survey in Timor Leste, a young and fragile state located in Southeast Asian region which has so far received very little attention on health research globally (Deen et al., 2013).

As is the case in many other developing economies of Asia, poverty and undernutrition remain the main contributors to maternal and child mortality in Timor Leste, presenting an unparalleled challenge for human development in the country (Haddad, Philpott-Jones \& Schonfeld, 2015). Since its independence in 2002, the government has made several initiatives to fight malnutrition among pregnant women such as free provision of iron supplementation among pregnant women. According to the nutrition strategy, all pregnant women are supplied with iron/folate acid tablets free of charge. Information on supplementary food intake were not collected in the latest Demographic and Health Survey (DHS), therefore we used data from round-2 (2009-10) to assess the relationship between supplementary food intake during pregnancy and lactation and nutritional status among children, as there is currently no research evidence on the effectiveness of such practice in Timor Leste. The findings of this study are expected to be of great value to the ongoing maternal and child nutrition programs in Timor Leste, as well as other countries in the region sharing similar sociodemographic characteristics.

\section{Method}

Setting: Democratic Republic of Timor-Leste, also known as East Timor or Timor-Leste, is the newest country located in the Asia Pacific region, and also one of the smallest in Asia in terms of total population. The country declared independence from Indonesia in 2002, after a prolonged period of conflict and destruction of economic and health infrastructures. As one of the least-developed countries, Timor Leste relies heavily on foreign aid for supporting its development agenda. The population is predominantly rural and engaged in subsistence agriculture. Median age of the population is 17.5 years with young people (014 years) constituting about $40 \%$ of the population ("Timor-Leste Age structure - Demographics"). The demography is characterized by high fertility (almost 6 children per women), and high maternal mortality rates (557 deaths per 100,000 deliveries) and under-five (64 deaths per 1000 births) mortality rates(Richards, 2015; Price et al., 2016). Survey description: Data for this study were extracted from the second round of Timor-Leste Demographic and Health Survey (TLDHS) conducted in 2009-10. The main 
objectives of the DHS surveys are to generate quality data on key sociodemographic indicators (e.g. maternal and child malnutrition, maternal healthcare use, HIV knowledge), monitoring national and international health related goals, and to assist in evidence-based policy making in the host countries. The survey was implemented by the National Statistics Directorate of the Directorate General for Analysis and Research of the Ministry of Finance with technical assistance from ICF Macro, and financial support by several international donors such from USAID and WHO.

The sampling process involved a two-stage selection strategy. Firstly, the selection of clusters from the 13 districts in both urban and rural areas, and secondly to select households from each cluster for interview. In total 455 clusters were selected (116 urban areas and 339 rural areas) from which 11,800 women were eligible for interview. Field work lasted from August 10 of 2009 to February 7 of 2010. The survey methods were published with more details elsewhere* (https://goo.gl/qASVXJ).

*National Statistics Directorate (NSD) [Timor-Leste], Ministry of Finance [Timor-Leste], and ICF Macro. 2010. Timor-Leste Demographic and Health Survey 2009-10. Dili, Timor-Leste: NSD [Timor- Leste] and ICF Macro.

\section{Variables used in the study}

\section{Outcome variable}

Outcome variables were three measures of child malnutrition: height-for-age (stunting), weight-for-age (underweight), and weight-for-height (wasting). These are commonly used and reliable indicators of nutritional status that provide information regarding growth and body composition among children under five years of age. These are measured in standard deviation units (z-scores) from the median of the reference population, as recommended by WHO (Gretchen et al., 2012).

Stunting is an indication of linear growth retardation associated with poor feeding practices, chronic inadequate intake of protein and energy and frequent infection. It was categorised as: Stunted (Height for age: HFA <-2 SD), and not stunted (HFA $\geq-2 S D$ ).

Wasting is an indication of acute undernutrition resulting from of insufficient food intake, failure to gain weight or weight loss, recurrent infectious diseases (e.g. diarrhea), or a combination of these factors. It was categorised as: Wasted (Weight for height: WFH $<-2 \mathrm{SD}$ ), and not wasted (WFH $\geq-2 S D$ ).

Underweight is a composite indicator of stunting and wasting that accounts for both acute and chronic malnutrition. It was categorised as: Underweight (Weight for age: WFA <-2 SD), and Not underweight (WFA $\geq-2 S D$ ).

\section{Independent variables}


Main explanatory variables were self-reported intake of supplementary food during pregnancy and lactation. These were assessed by the asking the participants: 1) Whether or not they took any supplementary food during most recent pregnancy (Yes/No), 2) Whether or not they took any supplementary food during lactation for their most recent child.

\section{Control variables}

To measure the independent association between the outcome and explanatory variables, the analysis was adjusted for a generous number of maternal and child level variables which are likely to influence nutritional status of children. The variables are listed and described in table-1.

\section{Data analysis}

Data analysis was performed using SPSS V. 24. The dataset was first checked to make sure it's free from outliers and collinearity issues. To meet the requirements of the study, mothers who were currently breastfeeding and responded the questions on supplementary food intake were included in the analysis. The prevalence of stunting, wasting and underweight, along with maternal and child level variables were presented as percentages with 95\% Confidence Intervals. Following that, the prevalence of each of the outcome variables according to the take of supplementary food during pregnancy and lactation were presented as bar charts. The final part of the analysis constituted a multivariable regression analysis to calculate the odds of association between stunting, wasting, undernutrition with the intake of supplementary food in three steps. The first step was univariate analysis (Model-1) without including any control variable in the model. In the second model the association was adjusted for maternal level variables (Model-2), while the last model adjusted for both maternal and child level variables (Model-3) to observe the differential contribution of these factors(Ghose et al., 2016). Maternal and child level variables were entered in different steps to find changes in Odds ratio for respective factors. Level of significance was set at $p<0.05$ for all analyses.

Ethical approval: All DHS survey protocols are approved by ICF international and a review board in the country of survey. Data were made available in the public domain in anonymised form. Therefore, no additional approval is necessary.

\section{Results}

\section{Descriptive statistics}

Study participants were 5993 mothers and their last-born child. Mean age of mothers and children was respectively 31.53 (31.34-31.72) and 1.32 (1.29-1.35) years. Sociodemographic characteristics of the mothers and children were presented in Table-1. 
225

226

227

\section{Prevalence of women who received supplementary food during pregnancy and lactation}

Less than one-third of the mothers reported taking supplementary food during pregnancy $(29.1 \%, 95 \% \mathrm{Cl}$ 27.2-31.0) and lactation $(31.0 \%, 95 \% \mathrm{Cl} 29.1-33.0)$, whereas the prevalence of taking iron supplement was close to three-fifth $(63.1 \%, 95 \% \mathrm{Cl} 60.9-65.3)$.

\section{Table-1}

\section{Prevalence of stunting, wasting, and underweight}

Table-1 also shows that more than one third of the children were stunted $(36.7 \%, 95 \% \mathrm{Cl} 35.1-38.3)$, underweight $(36.0,95 \% \mathrm{Cl} 34.5-37.7)$, and $12.5 \%(95 \% \mathrm{Cl} 11.5-13.5)$ were wasted.

Figure-1

Figure-1shows the prevalence of stunting (HFA<2SD) according the supplementary food intake status among urban and rural mothers. The figure indicates that mothers who took supplementary food during pregnancy and lactation had lower likelihood of having stunted children compared with those who did not. This was true in both urban and rural areas. Taking iron supplementation appeared to have a positive relationship with stunting; however, the difference was not statistically significant.

Figure-2

Figure-2 illustrates that the overall prevalence of having underweight (WFA $<2 S D)$ children was higher among mothers who did not take supplementary food during pregnancy and lactation. The same pattern was observed when the sample was stratified into urban and rural areas. In the chi-square tests, iron intake did not show any significant decrease in the probability of being underweight.

Figure-3 
262 Figure-3 illustrates that in both urban and rural areas mothers who did not take supplementary food

263

264

265

266 during pregnancy and lactation, iron supplementation during pregnancy, had a higher prevalence of having babies who are wasted (WFH<2SD).

\section{Sociodemographic correlates of taking supplementary food among pregnant and lactating mothers}

Table-2 shows the results of the multivariable regression on the association between supplementary food intake with the sociodemographic characteristics of the participants. The odds of taking supplementary food during pregnancy and lactation were lower among those in the younger age groups (20-34 years), higher among those in the urban areas, had 1-2 children. Surprisingly, women who had no education $(\mathrm{OR}=1.416,95 \% \mathrm{Cl}=1.104-2.011)$ and lived in the poor households $(\mathrm{OR}=1.427,95 \% \mathrm{Cl}=1.024-1.911)$ had higher odds of taking iron supplements during pregnancy. The odds of taking two or all three supplements were also higher among urban mothers compared with those in the rural areas.

\section{Table-2}

Multivariable association between supplementation intake during pregnancy and lactation and child nutritional outcomes

Table-3 summarises the results (odds ratios) of the association between supplementation intake during pregnancy and lactation with child stunting, underweight, and wasting. In general, compared with mother who reported taking supplementary food during pregnancy and lactation, those who did not take had higher odds of children with stunting, underweight, and wasting. The same was true for those who took supplementary food both during pregnancy and lactation, and took all three types supplementation compared with those who took none or only one (with a few exceptions). For instance, compared with mothers who had supplementary food during pregnancy and lactation, those did not have had respectively $1.61(\mathrm{OR}=1.610,95 \% \mathrm{Cl}=1.128-2.310)$ and $1.57(\mathrm{OR}=1.570,95 \% \mathrm{Cl}=1.108-2.127)$ times higher odds of having stunted and underweight children (Model-1). Those who had none of the supplements at any point had respectively $1.67(\mathrm{OR}=1.674,95 \% \mathrm{Cl}=1.118-2.087)$ and $1.63(\mathrm{OR}=1.631$, $95 \% \mathrm{Cl}=1.130-2.144)$ times higher odds of having stunted and underweight children. The strength of these associations decreased to some extent upon adjustment for the maternal (Model-2) and child level variables (Model-3), however remained statistically significant (except for wasting).

4

5

6

\section{Table-3}




\section{Discussion}

305

Findings of the present study based on the data from Demographic and Health Survey revealed a considerably high prevalence of undernutrition, especially of stunting and wasting among under-five children in Timor Leste. Characteristic of post-conflict communities, child malnutrition is rampant across the country and represents a serious public health concern. What is perhaps of greater concern is the notably low prevalence of taking supplementary food among women during pregnancy and lactation. Dietary supplementation during pregnancy may not be considered as an absolute necessity for a high income setting with stable provision of food and livelihood amenities. However, the current situation in Timor Leste characterized by a fragile agri-food sector and precarious state of food and nutrition insecurity (Molyneux et al., 2012) leave little doubt that micronutrient deficiency/hidden hunger must also be widespread and contributing to the high rates of child malnutrition.

According the findings, there remains certain sociodemographic patterns in the use of supplementary food among pregnant and lactating mothers in the country. Mothers who were comparatively younger and residents of rural areas were less likely to take supplementary food. No significant difference in taking supplementary food was observed across socioeconomic groups (wealth status and education). The reasons why mothers of certain age groups and regions are more deprived of this facility than others remain subject to further exploration.

Overall, the findings of the study revealed a positive association between maternal consumption of supplementary food and nutritional status of children, reaffirming the role of maternal dietary practices on nutritional well-being of child. Apart from few exceptions, intake of supplementary food during pregnancy and lactation proved to have beneficial influence on nutritional status among Timorese children. Oddly enough, iron intake was not significantly associated with any of the outcomes. Iron deficiency (anemia) constitutes a leading nutritional deficiency among women of childbearing age especially in the developing countries, and is routinely included in the integrated antenatal care package (Gautam et al., 2008). Therefore, the findings should be interpreted with caution as we could not adjust the analysis for indicators of iron deficiency, as well as diseases that affect iron metabolism. There remains a scarcity of evidence on dietary supplement during pregnancy and its impact on child nutritional outcomes as the studies have mostly been concerned with birth outcomes, which limits the scope of discussing the findings in contrast to past evidences. This is perhaps because birth outcomes serve as strong predictors 
336

of nutritional status among under-five children. In Nepal, Iron/Folate supplementation among pregnant women were reported to reduce the risk of stunting among children below 24 months of age (Ezeh et al., 2014). The beneficial effects of dietary supplementation during pregnancy on birthweight were reported in several other countries with high rates of child malnutrition in Africa e.g. Ghana (Adu-Afarwuah et al., 2015), Kenya (Maina-Gathigi et al., 2013), Malawi (Prado et al., 2016), and Asia e.g. Bangladesh (Mridha et al., 2016; Dewey et al., 2017), India (Aguayo et al., 2016).

\section{General discussion and policy recommendation}

Child malnutrition in Timor Leste stands at an alarming proportion, which is a potential indication of poor maternal health status and inadequate care and diet during pregnancy and lactation. Our findings show that majority of the women fail to take to advantage of taking supplementation during gestation. Important sociodemographic disparities were also observed in the prevalence of taking supplementary food. Being a country under the process of recovery from decades of political conflict and destruction of livelihood, the healthcare system in Timor Leste is faced with enormous challenges in terms of skilled human resource, inadequate research and development expenditures. These factors exert substantial cumulative effect on population health and nutrition, building a healthy workforce, and thereby can hamper socioeconomic development due to the cyclical nature of the relationship between poverty, health and national progress. In order to reverse this trend, the healthcare system need to make strategic planning and budget allocation for micronutrient supplementation and fortification programs that are proven cost-effective interventions for maternal and child malnutrition. Being a multi-ethnic population, uniform nutrition policy making may not address the contextual factors responsible for malnutrition and associated higher susceptibility to infectious diseases. We also observed a clear urban-rural disparity in the prevalence of supplementation food which indicates potential gaps in the coverage of the programs. Special attention is therefore necessary to address the regional gaps to make sure that all women can benefit from the programs regardless of their place of residence. Future studies should attempt to conduct qualitative studies and more nuanced analysis of sociocultural factors that influence nutritional practices such as use of supplementary/fortified food in the context of maternal and child malnutrition.

\section{Strengths and limitations}

To our knowledge, this is the first study to report the association between dietary supplementation during pregnancy and lactation and nutritional status of children. Previous studies have mostly focused on the birth outcomes and considered supplementation during pregnancy. For this study, supplementation during both pregnancy and lactation were considered as poor nutrition among lactating mothers has been shown to be associated with adverse health outcomes among infants (Keenan et al., 2013). Besides that, availability of large number of variable on the dataset allowed us to adjust the analysis for several maternal and child level variables. The sample size was also high and data were of good quality. Among 
373 the limitations are self-reported nature of several variables e.g. breastfeeding, intake of dietary 374 supplements. Also, the prevalence of stunting, wasting and underweight may not match with the original 375 survey as our study was limited only to the subsample who provided information on taking 376 supplementation during pregnancy and lactation, as these were the explanatory variables of interest. 377 There was no precise information on what type of dietary supplement was consumed. Precise information 378 on the micronutrient/s would help better clarify the beneficial role of the supplement. Data were cross379 sectional; hence no causal relationship can be established.

\section{Conclusion}

Findings of the study conclude that a great proportion of the women in Timor Leste remain deprived of the benefits of current supplementation programs. Significant socioeconomic variations exist in the uptake of dietary supplements that need to be taken into consideration to improve the coverage. A positive association was observed between maternal consumption and supplementary food and nutritional status of children, which reaffirms the previous findings regarding the role of maternal dietary practices on nutritional well-being children. Given the remarkably high prevalence of child malnutrition in the country, more strategic food and nutrition policy planning within the areas of maternal and child health should be targeted. Longitudinal studies are warranted to validate the causal association.

Acknowledgement: Authors would like to express sincere thanks to DHS program for providing the datasets used in this study.

Availability of data: Data used in this study are available through the website of DHS program.

\section{References}

Abdullahi H., Gasim GI., Saeed A., Imam AM., Adam I. 2014. Antenatal iron and folic acid supplementation use by pregnant women in Khartoum, Sudan. BMC Research Notes 7:498. DOI: 10.1186/1756-0500-7-498.

Abu-Saad K., Fraser D. 2010. Maternal Nutrition and Birth Outcomes. Epidemiologic Reviews 32:5-25. DOI: 10.1093/epirev/mxq001.

Adu-Afarwuah S., Lartey A., Okronipa H., Ashorn P., Zeilani M., Peerson JM., Arimond M., Vosti S., 
408

409

410

411

412

413

414

415

416

417

418

Dewey KG. 2015. Lipid-based nutrient supplement increases the birth size of infants of primiparous women in Ghana. The American Journal of Clinical Nutrition 101:835-846. DOI: 10.3945/ajcn.114.091546.

Aguayo VM., Nair R., Badgaiyan N., Krishna V. 2016. Determinants of stunting and poor linear growth in children under 2 years of age in India: an in-depth analysis of Maharashtra's comprehensive nutrition survey. Maternal \& Child Nutrition 12 Suppl 1:121-140. DOI: 10.1111/mcn.12259.

Bayley TM., Dye L., Jones S., DeBono M., Hill AJ. 2002. Food cravings and aversions during pregnancy: relationships with nausea and vomiting. Appetite 38:45-51. DOI: 10.1006/appe.2002.0470.

Belfort MB., Rifas-Shiman SL., Rich-Edwards JW., Kleinman KP., Oken E., Gillman MW. 2008. Maternal iron intake and iron status during pregnancy and child blood pressure at age 3 years. International journal of epidemiology 37:301-308. DOI: 10.1093/ije/dyn002.

Blumfield ML., Nowson C., Hure AJ., Smith R., Simpson SJ., Raubenheimer D., MacDonald-Wicks L., Collins CE. 2015. Lower Protein-to-Carbohydrate Ratio in Maternal Diet is Associated with Higher Childhood Systolic Blood Pressure up to Age Four Years. Nutrients 7:3078-3093. DOI: 10.3390/nu7053078.

Brenseke B., Prater MR., Bahamonde J., Gutierrez JC. 2013. Current Thoughts on Maternal Nutrition and Fetal Programming of the Metabolic Syndrome. Journal of Pregnancy 2013. DOI: $10.1155 / 2013 / 368461$

Bulik CM., Von Holle A., Siega-Riz AM., Torgersen L., Lie KK., Hamer RM., Berg CK., Sullivan P., Reichborn-Kjennerud T. 2009. Birth Outcomes in Women with Eating Disorders in the Norwegian Mother and Child Cohort Study (MoBa). The International journal of eating disorders 42:9-18. DOI: 10.1002/eat.20578.

Deen J., Matos L da C., Temple B., Su J-Y., da Silva J., Liberato S., da Silva V., Soares Al., Joshi V., Moon S., Tulloch J., Martins J., Mulholland K. 2013. Identifying national health research priorities in Timor-Leste through a scoping review of existing health data. Health Research Policy and Systems 11:8. DOI: 10.1186/1478-4505-11-8.

Dewey KG., Mridha MK., Matias SL., Arnold CD., Cummins JR., Khan MSA., Maalouf-Manasseh Z., Siddiqui Z., Ullah MB., Vosti SA. 2017. Lipid-based nutrient supplementation in the first $1000 \mathrm{~d}$ 
improves child growth in Bangladesh: a cluster-randomized effectiveness trial. The American Journal of Clinical Nutrition 105:944-957. DOI: 10.3945/ajcn.116.147942.

Dinas K., Daniilidis A., Sikou K., Tantanasis T., Kasmas S., Tzafettas J. 2008. Anorexia nervosa in pregnancy: a case report and review of the literature. Obstetric Medicine 1:97-98. DOI: 10.1258/om.2008.080026.

Ezeh OK., Agho KE., Dibley MJ., Hall J., Page AN. 2014. The Impact of Water and Sanitation on Childhood Mortality in Nigeria: Evidence from Demographic and Health Surveys, 2003-2013. International Journal of Environmental Research and Public Health 11:9256-9272. DOI: 10.3390/ijerph110909256.

Gautam CS., Saha L., Sekhri K., Saha PK. 2008. Iron Deficiency in Pregnancy and the Rationality of Iron Supplements Prescribed During Pregnancy. The Medscape Journal of Medicine 10:283.

Gernand AD., Schulze KJ., Stewart CP., West KP., Christian P. 2016. Micronutrient deficiencies in pregnancy worldwide: health effects and prevention. Nature Reviews. Endocrinology 12:274-289. DOI: $10.1038 /$ nrendo.2016.37.

Ghose B., Tang S., Yaya S., Feng Z. 2016. Association between food insecurity and anemia among women of reproductive age. PeerJ 4. DOI: 10.7717/peerj.1945.

Gretchen A Stevens, Mariel M Finucane, Christopher J Paciorek, Seth R Flaxman, Richard A White, Abigail J Donner, Majid Ezzati. Trends in mild, moderate, and severe stunting and underweight, and progress towards MDG 1 in 141 developing countries: a systematic analysis of population representative data. Lancet. 2012 Sep 1; 380(9840): 824-834.

Haddad LB., Philpott-Jones S., Schonfeld T. 2015. Contraception and prevention of HIV transmission: a potential conflict of public health principles. The Journal of Family Planning and Reproductive Health Care 41:20-23. DOI: 10.1136/jfprhc-2013-100844.

Hirschberg AL. 2012. Sex hormones, appetite and eating behaviour in women. Maturitas 71:248-256. DOI: 10.1016/j.maturitas.2011.12.016.

Keenan K., Bartlett TQ., Nijland M., Rodriguez JS., Nathanielsz PW., Zürcher NR. 2013. Poor nutrition during pregnancy and lactation negatively affects neurodevelopment of the offspring: evidence from a translational primate model123. The American Journal of Clinical Nutrition 98:396-402. 
DOI: 10.3945/ajcn.112.040352.

Khanal V., Zhao Y., Sauer K. 2014. Role of antenatal care and iron supplementation during pregnancy in preventing low birth weight in Nepal: comparison of national surveys 2006 and 2011. Archives of Public Health 72:4. DOI: 10.1186/2049-3258-72-4.

Koubaa S., Kouba S., Hällström T., Lindholm C., Hirschberg AL. 2005. Pregnancy and neonatal outcomes in women with eating disorders. Obstetrics and Gynecology 105:255-260. DOI: 10.1097/01.AOG.0000148265.90984.c3.

Lowdon J. 2008. Getting bone health right from the start! Pregnancy, lactation and weaning. The Journal of Family Health Care 18:137-141.

Maina-Gathigi L., Omolo J., Wanzala P., Lindan C., Makokha A. 2013. Utilization of folic acid and iron supplementation services by pregnant women attending an antenatal clinic at a regional referral hospital in Kenya. Maternal and Child Health Journal 17:1236-1242. DOI: 10.1007/s10995-0121120-x.

Marangoni F., Cetin I., Verduci E., Canzone G., Giovannini M., Scollo P., Corsello G., Poli A. 2016. Maternal Diet and Nutrient Requirements in Pregnancy and Breastfeeding. An Italian Consensus Document. Nutrients 8. DOI: 10.3390/nu8100629.

Molyneux N., da Cruz GR., Williams RL., Andersen R., Turner NC. 2012. Climate Change and Population Growth in Timor Leste: Implications for Food Security. Ambio 41:823-840. DOI: 10.1007/s13280012-0287-0.

Mridha MK., Matias SL., Chaparro CM., Paul RR., Hussain S., Vosti SA., Harding KL., Cummins JR., Day LT., Saha SL., Peerson JM., Dewey KG. 2016. Lipid-based nutrient supplements for pregnant women reduce newborn stunting in a cluster-randomized controlled effectiveness trial in Bangladesh. The American Journal of Clinical Nutrition 103:236-249. DOI: 10.3945/ajcn.115.111336.

Orloff NC., Flammer A., Hartnett J., Liquorman S., Samelson R., Hormes JM. 2016. Food cravings in pregnancy: Preliminary evidence for a role in excess gestational weight gain. Appetite 105:259265. DOI: 10.1016/j.appet.2016.04.040.

Prado EL., Maleta K., Ashorn P., Ashorn U., Vosti SA., Sadalaki J., Dewey KG. 2016. Effects of maternal 
and child lipid-based nutrient supplements on infant development: a randomized trial in Malawi. The American Journal of Clinical Nutrition 103:784-793. DOI: 10.3945/ajcn.115.114579.

Price JA., Soares AIFS., Asante AD., Martins JS., Williams K., Wiseman VL. 2016. "I go I die, I stay I die, better to stay and die in my house": understanding the barriers to accessing health care in TimorLeste. BMC Health Services Research 16. DOI: 10.1186/s12913-016-1762-2.

Richards E. 2015. The Catholic Church and reproductive health and rights in Timor-Leste: contestation, negotiation and cooperation. Culture, Health \& Sexuality 17:343-358. DOI: 10.1080/13691058.2014.966255.

Szostak-Wegierek D. 2014. Intrauterine nutrition: long-term consequences for vascular health. International Journal of Women's Health 6:647-656. DOI: 10.2147/IJWH.S48751.

Timor-Leste Age structure - Demographics. Available at https://www.indexmundi.com/timorleste/age_structure.html (accessed April 14, 2018).

Tsui B., Dennehy CE., Tsourounis C. 2001. A survey of dietary supplement use during pregnancy at an academic medical center. American Journal of Obstetrics and Gynecology 185:433-437. DOI: 10.1067/mob.2001.116688.

Vitamin A supplementation during pregnancy for maternal and newborn health outcomes | Cochrane. Available at /CD008666/PREG_vitamin-supplementation-during-pregnancy-maternal-andnewborn-health-outcomes (accessed April 14, 2018). DOI: 10.1002/14651858.CD008666.pub3.

Wen X., Triche EW., Hogan JW., Shenassa ED., Buka SL. 2011. Prenatal Factors for Childhood Blood Pressure Mediated by Intrauterine and/or Childhood Growth? Pediatrics 127:e713-e721. DOI: 10.1542/peds.2010-2000.

van der Wijden CL., Steinbach S., van der Ploeg HP., van Mechelen W., van Poppel MNM. 2014. A longitudinal study on the relationship between eating style and gestational weight gain. Appetite 83:304-308. DOI: 10.1016/j.appet.2014.09.001. 


\section{Table 1 (on next page)}

Maternal demographic and socioeconomic characteristics $(n=5993)$. 
Table-1: Maternal demographic and socioeconomic characteristics $(n=5993)$.

\begin{tabular}{lcl}
\hline Variable description & $\%$ & $\begin{array}{l}95 \% \mathrm{CI} \\
\text { (Lower- } \\
\end{array}$ \\
& & Upper) \\
\hline Maternal-level variables & \\
\hline
\end{tabular}

Residency type Urbanicity of the place of residence

Urban

Rural

Religion

Roman catholic

Other

Education

Nil

Primary

Secondary/higher

Parity (Mean)

1-2

3-4

$>4$

\section{BMI}

Normal weight

Overweight

Obese

Household wealth status

Poor

Non-poor

During pregnancy

had

supplementary

food

No

Yes

\section{During lactation}

had

supplementary

food

No

Yes

During pregnancy had iron supplements
24.6

$23.1-26.3$

75.4

73.7- 76.9

Religious affiliation of the respondent

$98.0 \quad 97.3-98.5$

$2.0 \quad 1.5-2.7$

Educational level attained based on number of formal schooling years

32.9

$31.0-34.8$

$27.5 \quad 26.0-29.1$

$39.6 \quad 37.242$

Number of children ever born $\quad 4.40 \quad 4.334 .46$

$28.8 \quad 27.3-30.3$

$28.4 \quad 27.1-29.7$

$42.8 \quad 41.2-44.5$

Individual's weight in kilograms $(\mathrm{kg})$ divided by height in meters squared $\left(\mathrm{m}^{2}\right)$

23.7

22.4- 25.1

$68.3 \quad 66.7-69.9$

$8.0 \quad 7.1-9.1$

Wealth status assessed based on wealth quintile: lowest/lower quintile $=$ Poor, and middle/higher/highest= Non-poor.

$39.9 \quad 37.5-42.2$

$60.1 \quad 57.8-62.5$ Self-reported status of supplementary food intake during pregnancy

$70.9 \quad 69.0-72.8$

$29.1 \quad 27.2-31.0$

Self-reported status of supplementary food intake during lactation

$68.9 \quad 67.0-70.8$

$31.0 \quad 29.1-33.0$ 


\begin{tabular}{|c|c|c|c|}
\hline $\begin{array}{l}\text { No } \\
\text { Yes }\end{array}$ & & $\begin{array}{l}36.9 \\
63.1\end{array}$ & $\begin{array}{c}34.7-39.1 \\
60.9-65.3\end{array}$ \\
\hline \multicolumn{4}{|l|}{ Child-level variables } \\
\hline Sex & Sex of the child & & \\
\hline Male & & 51.9 & 50.4- 53.4 \\
\hline Female & & 48.1 & 46.6- 49.6 \\
\hline Birth type & Whether or not birth was singleton & & \\
\hline Singleton & & 99.0 & $98.7-99.2$ \\
\hline Twin & & 1.0 & $0.8-1.3$ \\
\hline Skilled birth & Birth took place at home or a health & & \\
\hline No & facility & 74.8 & $72.8-76.8$ \\
\hline Yes & & 25.2 & $23.2-27.2$ \\
\hline $\begin{array}{l}\text { Had early } \\
\text { initiation of BF }\end{array}$ & $\begin{array}{l}\text { Breastfeeding started within } 1 \mathrm{~h} \text { of } \\
\text { birth }\end{array}$ & & \\
\hline No & & 9.90 & $9.0-10.9$ \\
\hline Yes & & 90.1 & $89.1-91.0$ \\
\hline $\begin{array}{ll}\text { Taking } & \text { iron } \\
\text { supplements } & \end{array}$ & $\begin{array}{l}\text { Whether or not currently taking iron } \\
\text { pills/sprinkles/syrup }\end{array}$ & & \\
\hline No & & 79.5 & 78.2- 80.8 \\
\hline Yes & & 20.3 & $19.0-21.6$ \\
\hline Stunted & Height/age below $<2$ SD & & \\
\hline Yes & & 36.7 & $35.1-38.3$ \\
\hline No & & 63.3 & $61.7-64.9$ \\
\hline Underweight & Weight/age below $<2$ SD & & \\
\hline Yes & & 36.0 & $34.5-37.7$ \\
\hline No & & 64.0 & $62.3-65.5$ \\
\hline Wasted & Weight/height below $<2 \mathrm{SD}$ & & \\
\hline Yes & & 12.5 & $11.5-13.5$ \\
\hline No & & 87.5 & $86.5-88.5$ \\
\hline
\end{tabular}




\section{Table 2 (on next page)}

Odds ratio of taking supplementary food during pregnancy and lactation in Timor Leste. 
1

2 Table-2: Odds ratio of taking supplementary food during pregnancy and lactation in 3 Timor Leste.

\begin{tabular}{|c|c|c|c|c|c|}
\hline & $\begin{array}{l}\text { During } \\
\text { pregnancy } \\
\text { had } \\
\text { supplementar } \\
\text { y food }\end{array}$ & $\begin{array}{l}\text { During } \\
\text { lactation had } \\
\text { supplementar } \\
\text { y food }\end{array}$ & $\begin{array}{l}\text { During } \\
\text { pregnancy } \\
\text { had iron } \\
\text { supplements }\end{array}$ & $\begin{array}{l}\text { Two } \\
\text { supplementat } \\
\text { ions* }\end{array}$ & $\begin{array}{l}\text { Three } \\
\text { supplementat } \\
\text { ions** }\end{array}$ \\
\hline $\begin{array}{l}\text { Age groups } \\
(45-49)\end{array}$ & & & & & \\
\hline $15-19$ & $0.683^{\mathrm{ns}}$ & $0.634^{\mathrm{ns}}$ & $0.996^{\mathrm{ns}}$ & $0.704^{\mathrm{ns}}$ & $0.796^{\mathrm{ns}}$ \\
\hline $20-24$ & 0.585 & 0.510 & $0.904^{\mathrm{ns}}$ & 0.514 & $0.744^{\mathrm{ns}}$ \\
\hline $25-29$ & 0.706 & 0.617 & $0.8011^{\mathrm{ns}}$ & 0.639 & $0.778^{\mathrm{ns}}$ \\
\hline $30-34$ & 0.704 & 0.619 & $0.767^{\mathrm{ns}}$ & 0.640 & $0.867 \mathrm{~ns}$ \\
\hline $35-39$ & $0.914^{\mathrm{ns}}$ & $0.764^{\mathrm{ns}}$ & $0.785^{\mathrm{ns}}$ & $0.857^{\mathrm{ns}}$ & $10.057 \mathrm{~ns}$ \\
\hline $40-44$ & $0.891^{\mathrm{ns}}$ & 0.657 & $0.906^{\mathrm{ns}}$ & $0.801^{\mathrm{ns}}$ & $0.950^{\mathrm{ns}}$ \\
\hline $\begin{array}{l}\text { Residency } \\
\text { type (Rural) } \\
\text { Urban }\end{array}$ & 4.168 & 4.006 & $0.548^{\mathrm{ns}}$ & 4.531 & 3.599 \\
\hline $\begin{array}{l}\text { Religion } \\
\text { (Other) } \\
\text { Roman } \\
\text { catholic } \\
\text { Education } \\
\text { (Secondary/h } \\
\text { igher) }\end{array}$ & 1.590 & $0.861^{\mathrm{ns}}$ & $1.052^{\mathrm{ns}}$ & $1.016^{\mathrm{ns}}$ & $1.284^{\mathrm{ns}}$ \\
\hline $\begin{array}{l}\text { Nil } \\
\text { Primary } \\
\text { Parity }(>4)\end{array}$ & $\begin{array}{l}0.892^{\text {ns }} \\
0.909^{\text {ns }}\end{array}$ & $\begin{array}{l}0.877^{\mathrm{ns}} \\
0.898^{\mathrm{ns}}\end{array}$ & $\begin{array}{l}1.416 \\
0.968^{\mathrm{ns}}\end{array}$ & $\begin{array}{l}0.887^{n s} \\
0.885^{n s}\end{array}$ & $\begin{array}{l}0.958^{\mathrm{ns}} \\
0.846^{\mathrm{ns}}\end{array}$ \\
\hline $\begin{array}{l}1-2 \\
3-4 \\
\text { ВMI }\end{array}$ & $\begin{array}{l}1.153 \\
1.000^{\mathrm{ns}}\end{array}$ & $\begin{array}{l}1.193 \\
0.991^{\mathrm{ns}}\end{array}$ & $\begin{array}{l}0.856^{\mathrm{ns}} \\
0.840^{\mathrm{ns}}\end{array}$ & $\begin{array}{l}1.352 \\
1.025^{\mathrm{ns}}\end{array}$ & $\begin{array}{l}1.267 \\
0.950\end{array}$ \\
\hline $\begin{array}{l}\text { Normal } \\
\text { weight }\end{array}$ & $0.751^{\mathrm{ns}}$ & 0.679 & $0.722^{\mathrm{ns}}$ & 0.731 & $0.574^{\mathrm{ns}}$ \\
\hline $\begin{array}{l}\text { Overweight } \\
\text { Household } \\
\text { wealth status }\end{array}$ & $0.845^{\mathrm{ns}}$ & $0.861^{\mathrm{ns}}$ & $0.857^{\mathrm{ns}}$ & $0.831^{\mathrm{ns}}$ & $0.722^{\mathrm{ns}}$ \\
\hline
\end{tabular}




\section{(Non-poor)}

Poor $1.089^{\text {ns }}$

$1.144^{\mathrm{ns}}$

1.427

1.176

$1.032^{\mathrm{ns}}$

4 N.B. ns $=$ Not significant $(\mathrm{p}>0.05)$. $*$ Two supplementations $=$ During pregnancy had supplementary

5 food + During lactation had supplementary food; **Three supplementations $=$ During pregnancy

6 had supplementary food+ During lactation had supplementary food+ During pregnancy had iron

7 supplements. (Reference) categories in parenthesis. 


\section{Table 3 (on next page)}

Odds ratios of child stunting, underweight and wasting among mother who did not take supplementary food during pregnancy and lactation in Timor Leste (2009-10). 
1 Table-3: Odds ratios of child stunting, underweight and wasting among mother who did

2 not take supplementary food during pregnancy and lactation in Timor Leste (2009-10).

\begin{tabular}{|c|c|c|c|c|c|c|c|c|c|}
\hline & \multicolumn{3}{|c|}{ Model-1 } & \multicolumn{3}{|c|}{ Model-2 } & \multicolumn{3}{|c|}{ Model-3 } \\
\hline & $\begin{array}{l}\text { Stunti } \\
\text { ng }\end{array}$ & $\begin{array}{l}\text { Under } \\
\text { weight }\end{array}$ & $\begin{array}{l}\text { Wasti } \\
\text { ng }\end{array}$ & $\begin{array}{l}\text { Stunti } \\
\text { ng }\end{array}$ & $\begin{array}{l}\text { Under } \\
\text { weight }\end{array}$ & $\begin{array}{l}\text { Wasti } \\
\text { ng }\end{array}$ & $\begin{array}{l}\text { Stunti } \\
\text { ng }\end{array}$ & $\begin{array}{l}\text { Under } \\
\text { weight }\end{array}$ & $\begin{array}{l}\text { Wasti } \\
\text { ng }\end{array}$ \\
\hline $\begin{array}{l}\text { During } \\
\text { pregnancy } \\
\text { had } \\
\text { supplemen } \\
\text { tary } \\
\text { food(Yes) } \\
\text { No }\end{array}$ & 1.435 & 1.328 & $1.157^{\mathrm{ns}}$ & 1.339 & 1.262 & $0.879^{\mathrm{ns}}$ & 1.360 & 1.152 & $0.906^{\mathrm{ns}}$ \\
\hline $\begin{array}{l}\text { During } \\
\text { lactation } \\
\text { had } \\
\text { supplemen } \\
\text { tary } \\
\text { food(Yes) }\end{array}$ & & & & & & & & & \\
\hline No & 1.709 & 1.672 & $1.130^{\mathrm{ns}}$ & 1.603 & 1.589 & $1.042^{\mathrm{ns}}$ & 1.307 & 1.426 & $1.061^{\mathrm{ns}}$ \\
\hline $\begin{array}{l}\text { During } \\
\text { pregnancy } \\
\text { had iron } \\
\text { supplemen } \\
\text { ts(Yes) } \\
\text { No }\end{array}$ & $0.997^{\mathrm{ns}}$ & $1.082^{\mathrm{ns}}$ & $0.957^{\mathrm{ns}}$ & $1.074^{\mathrm{ns}}$ & $1.146^{\mathrm{n}}$ & 1.198 & $1.025^{\mathrm{ns}}$ & $1.120^{\mathrm{ns}}$ & 1.226 \\
\hline $\begin{array}{l}\text { Two } \\
\text { supplemen } \\
\text { tations* } \\
\text { (Yes) } \\
\text { No }\end{array}$ & 1.61 & 1.570 & 1.138 & 1.487 & 1.491 & $1.253^{\mathrm{ns}}$ & 1.221 & 1.334 & 1.130 \\
\hline $\begin{array}{l}\text { Three } \\
\text { supplemen } \\
\text { tations*** } \\
\text { No }\end{array}$ & 1.674 & 1.631 & $1.009^{\mathrm{ns}}$ & 1.554 & 1.541 & 1.017 & 1.309 & 1.371 & $1.163^{\mathrm{ns}}$ \\
\hline $\begin{array}{l}\text { N.B. ns= } \\
\text { food }+ \text { Dur } \\
\text { had supple } \\
\text { supplemen }\end{array}$ & $\begin{array}{l}\text { t signific } \\
\text { g lactat } \\
\text { entary } \mathrm{f} \\
\text { ( Refer }\end{array}$ & $\begin{array}{l}\text { nt }(p>0 \text {. } \\
\text { n had st } \\
\text { od+ Dur } \\
\text { ce) cate }\end{array}$ & $\begin{array}{l}\text { ). }{ }^{*} \text { Two } \\
\text { plement } \\
\text { g lactati } \\
\text { ories in } p\end{array}$ & $\begin{array}{l}\text { upplem } \\
\text { y food } \\
\text { n had s } \\
\text { renthes }\end{array}$ & $\begin{array}{l}\text { tations= } \\
\text { *Three } \\
\text { plement } \\
\text { Model- }\end{array}$ & $\begin{array}{l}\text { ouring } \mathrm{p} \text { } \\
\text { opplemei } \\
\mathrm{y} \text { food }+ \\
=\text { unadju }\end{array}$ & $\begin{array}{l}\text { gnancy } \\
\text { ations= } \\
\text { During } \\
\text { ed; Mo }\end{array}$ & $\begin{array}{l}\text { d suppl } \\
\text { uring p } \\
\text { gnancy } \\
-2=A d j\end{array}$ & $\begin{array}{l}\text { gentary } \\
\text { gnancy } \\
\text { ad iron } \\
\text { ted for }\end{array}$ \\
\hline
\end{tabular}




\section{Figure 1}

Comparative prevalence of stunting by supplementation intake during pregnancy and lactation stratified by type of residency in Timor Leste (2009-10).

The prevalence of stunting (HFA $<2 S D$ ) according the supplementary food intake status among urban and rural mothers. The figure indicates that mothers who took supplementary food during pregnancy and lactation had lower likelihood of having stunted children compared with those who did not. This was true in both urban and rural areas. Taking iron supplementation appeared to have a positive relationship with stunting; however, the difference was not statistically significant.

A

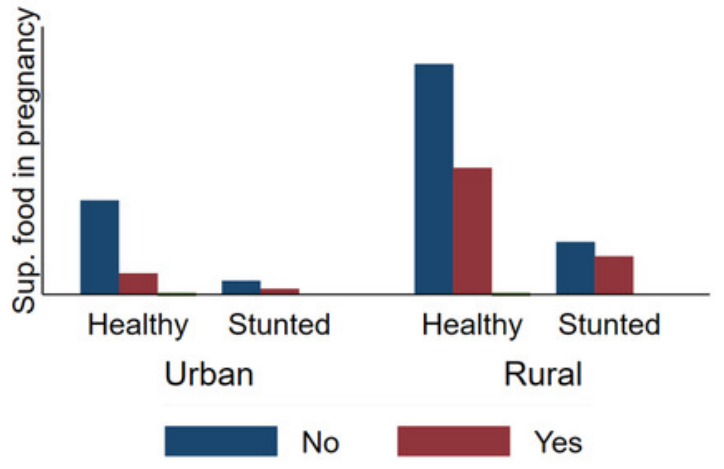

B

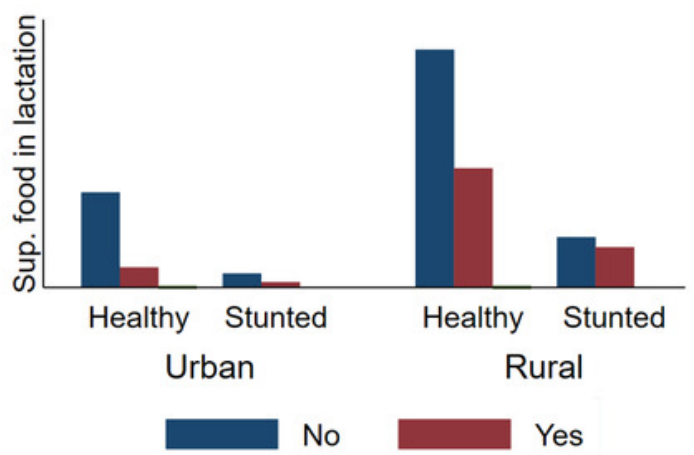

C

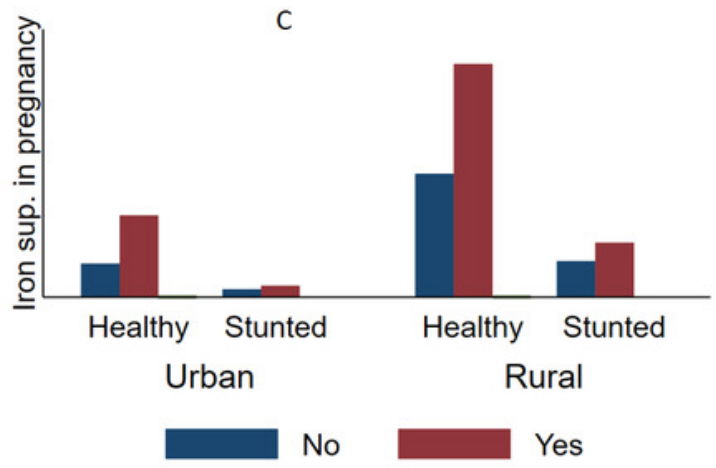




\section{Figure 2}

Comparative prevalence of underweight by supplementation intake during pregnancy and lactation stratified by type of residency in Timor Leste (2009-10).

Figure-2 illustrates that the overall prevalence of having underweight (WFA $<2 S D$ ) children was higher among mothers who did not take supplementary food during pregnancy and lactation. The same pattern was observed when the sample was stratified into urban and rural areas. In the chi-square tests, iron intake did not show any significant decrease in the probability of being underweight.

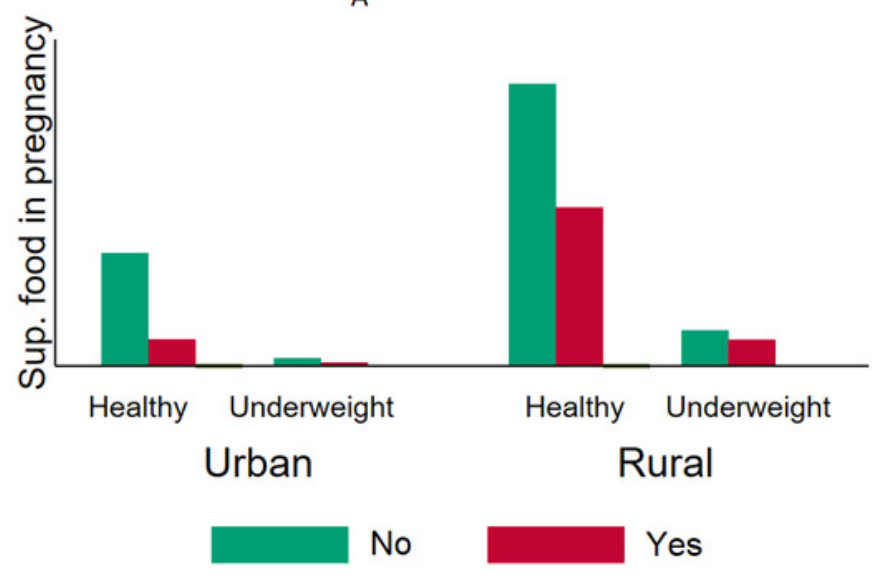

C

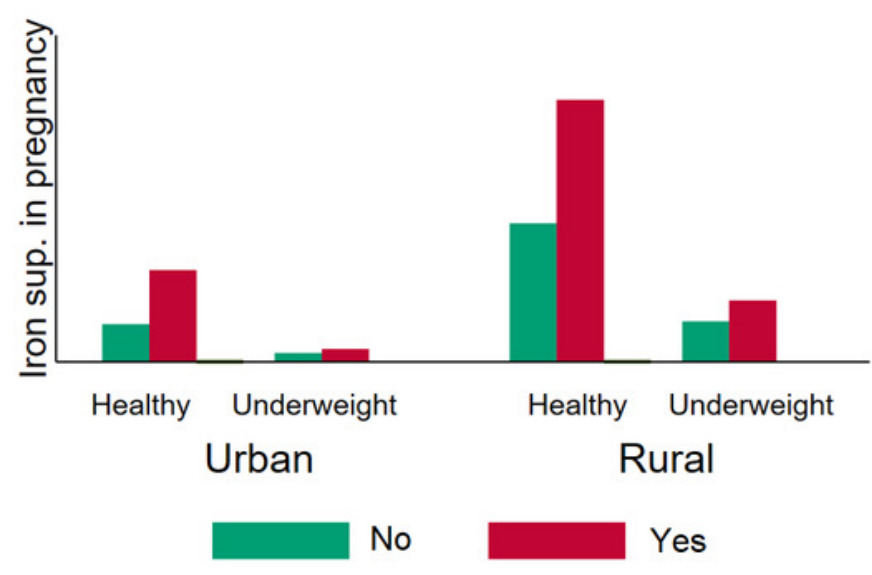

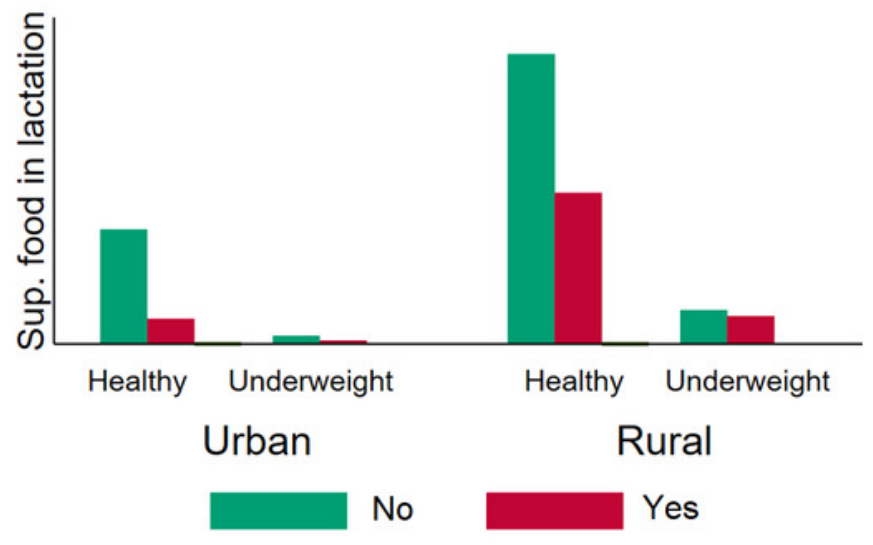


Figure 3

Comparative prevalence of infant wasting by iron supplementation during pregnancy and lactation stratified by type of residency in Timor Leste (2009-10).

Figure-3 illustrates that in both urban and rural areas mothers who did not take supplementary food during pregnancy and lactation, iron supplementation during pregnancy, had a higher prevalence of having babies who are wasted (WFH $<2 S D$ ).

A
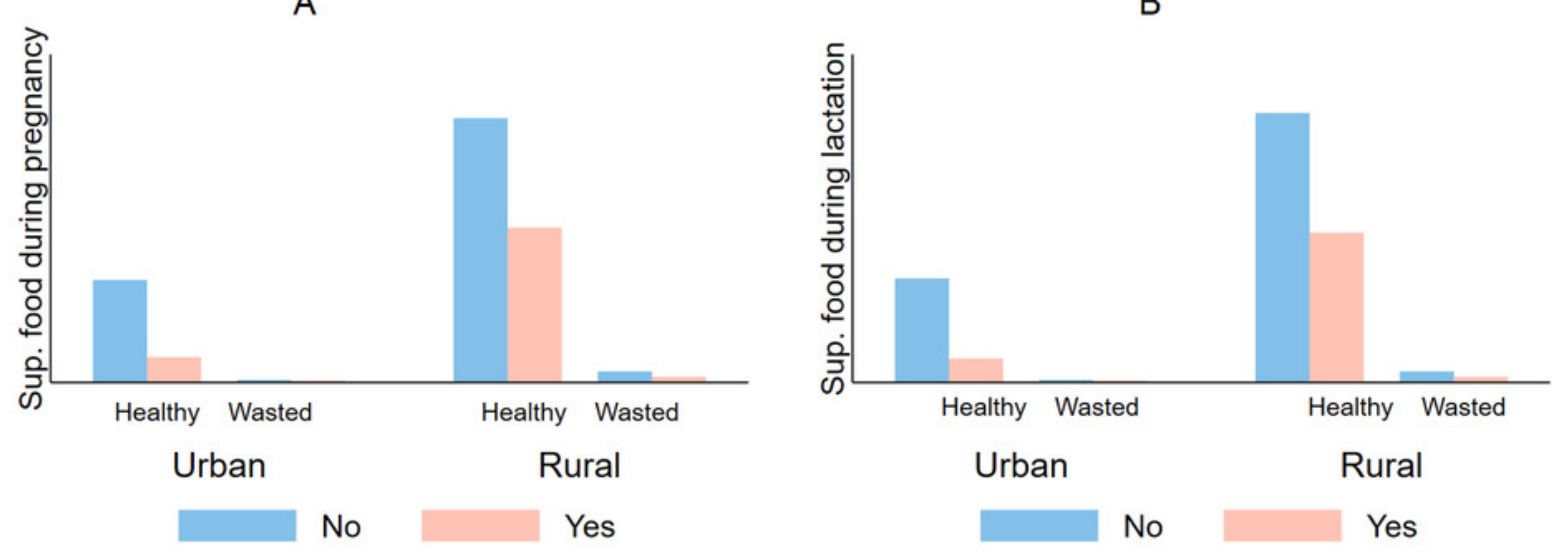

C

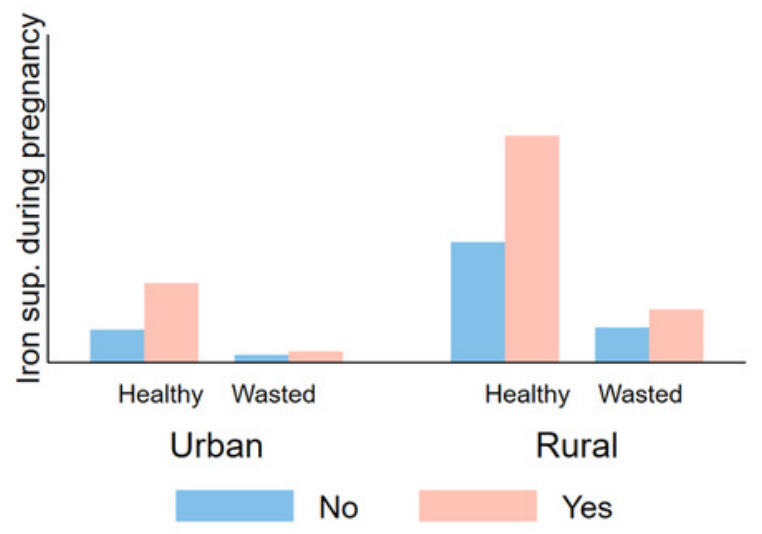

